\title{
Analisis Potensi Fermentasi Tepung Daun Binahong Anredera Cordifolia Dengan Metode Trial End Error Sebagai Pakan Tambahan Pada Ayam Petelur
}

\author{
Potential Analysis of Fermentation of Binahong Leaf Flour (Anredera Cordifolia) Using \\ Trial End Error Method As Additional Feed On Layer
}

\author{
Andi Randi Salim¹, Muhammad Ansar ${ }^{1}$, Alif Fachrur Al Hijazi ${ }^{2}$, Muhammad Idrus ${ }^{1}$, \\ Sri Firmiaty ${ }^{*}$ \\ *Email: sri.firmiaty@universitasbosowa.ac.id \\ ${ }^{1}$ Program Studi Peternakan, Fakultas Pertanian, Universitas Bosowa \\ ${ }^{2}$ Program Studi Agroteknologi, Fakultas Pertanian, Universitas Bosowa
}

Diterima: 15 September 2021 / Disetujui: 24 Desember 2021

\begin{abstract}
ABSTRAK
Ayam petelur merupakan ternak yang mudah stress dan rentan terhadap penyakit. Guna mengatasi keadaan tersebut perlu dicari alternatif bahan herbal yang tidak menimbulkan residu pada telur ayam yaitu dengan memberikan pakan tambahan fermentasi tepung daun binahong. Binahong merupakan salah satu tanaman yang dapat meningkatkan vitalitas dan daya tahan tubuh. Kandungan fitobiotik pada tepung daun binahong (fenol $85,30 \mathrm{mg} / \mathrm{kg}$, total flafonoid $47,40 \mathrm{mg} / \mathrm{kg}$, saponin $66,00 \mathrm{mg} / \mathrm{kg}$, dan alkaloid $2,60 \mathrm{mg} / \mathrm{kg}$ ). Unggas yang memiliki sistem pencernaan tunggal kurang baik dalam mencerna pakan berserat kasar tinggi. Kebutuhan serat kasar pada ayam petelur maksimal 7\% maka, dilakukan analisis manfaat fermentasi menggunakan EM4. Dalam penelitian terdahulu menyebutkan bahwa EM4 menghasilkan sejumlah besar enzim mencerna serat kasar seperti selulase dan mannase. Keuntungan Lactobacillus dalam EM4 dalam mencerna serat kasar adalah karena bakteri tidak menghasilkan serat kasar dalam aktivitasnya, sehingga mereka lebih efektif dalam menurunkan serat kasar. Fermentasi dapat meningkatkan nilai gizi dan juga palatabilitas. Pemberian pakan tambahan fermentasi tepung daun binahong sebagai feed adiktif memiliki potensi terhadap peningkatkan sistem imun sehingga ayam sehat, maka produksi telur akan meningkat dan stabil.
\end{abstract}

Kata Kunci: Fermentasi, Tepung Daun Binahong, Ayam Petelur

\begin{abstract}
Laying hens are animals that are easily stressed and susceptible to disease. In order to overcome this situation, it is necessary to find alternative herbal ingredients that do not cause residues in chicken eggs, namely by providing additional feed with fermented binahong leaf flour. Binahong is one of the plants that can increase vitality and endurance. Phytobiotic content in binahong leaf flour (phenol $85.30 \mathrm{mg} / \mathrm{kg}$, total flavonoids $47.40 \mathrm{mg} / \mathrm{kg}$, saponins $66.00 \mathrm{mg} / \mathrm{kg}$, and alkaloids $2.60 \mathrm{mg} / \mathrm{kg}$ ). Poultry that has a single digestive system is not good at digesting high crude fiber feed. The need for crude fiber in laying hens is a maximum of 7\%, so an analysis of the benefits of fermentation using EM4 was carried out. In previous studies, it was stated that EM4 produces a large number of enzymes digesting crude fiber such as cellulase and mannase. The advantage of Lactobacillus in EM4 in digesting crude fiber is that bacteria do not produce crude fiber in their activity, so they are more effective in reducing crude fiber. Fermentation can increase nutritional value and also palatability. The addition of fermented binahong leaf flour feed as an addictive feed has the potential to increase the immune system so that chickens are healthy, so egg production will increase and be stable.
\end{abstract}

Keywords: Fermentation, Binahong Leaf Flour, Layer Chicken

This work is licensed under Creative Commons Attribution License 4.0 CC-BY International license 


\section{A. PENDAHULUAN}

Industri ayam ras petelur telah berkembang pesat akibat tingginya permintaan telur sebagai salah satu produk pangan hewani yang banyak dibutuhkan masyarakat. Populasi ayam ras petelur komersil terus meningkat setiap tahunnya (Dirjen Peternakan dan Kesehatan Hewan, 2014). Namun, pemeliharaan ayam ras petelur yang dilakukan banyak peternak masih memiliki produktivitas yang belum optimal, disebabkan belum tercapainya standar produksi dari genetik ayam. Berdasarkan fakta yang terjadi di lapangan bahwa, faktor terbesar terjadi penurunan produksi telur pada ayam petelur adalah penyakit. Penyakit yang dapat menurunkan produksi telur yaitu akibat serangan virus IB (Infectious Bronchitis) berkisar $10-50 \%$, EDS (Egg Drop Syndrome) menurun $20-40$ $\%$ dan AI (Avian Influenza) bisa mencapai $80 \%$, sedangkan pada kasus ND (Newcastle Disease) berbeda-beda tergantung dari status kekebalan atau sistem imun pada ayam (Anonim, 2011). Sistem imun adalah sistem yang sangat penting bagi tubuh untuk menghindari dan melawan berbagai penyakit (Abbas dkk., 2007).
Kekebalan tubuh seekor ternak dilihat dari jumlah leukosit. Leukosit merupakan salah satu suspensi plasma darah yang berfungsi sebagai sistem pertahanan tubuh dari serangan bakteri, virus dan patogen melalui mekanisme pembentukan antibodi yang saat ini banyak digunakan sebagai salah satu indikator penentu kesehatan ternak. Status kesehatan ternak dapat diketahui melalui jumlah sel darah putihnya yang memiliki agen penyerang untuk melawan bakteri (Yuniwarti, 2015). Hampir semua penyakit dapat menurunkan produksi telur karena dapat membuat stress dan kesehatan terganggu termasuk pengaturan fungsi bertelur. Hal ini disebabkan karena kurang zat antibodi dalam tubuh sehingga terganggunya sistem imun hewan tersebut, yang berakibat mudah terserang penyakit. Ayam petelur yang terserang penyakit, maka terjadi penurunan pada produksi telur, selanjutnya akan berdampak pada peternak secara langsung karena dapat menurunkan omset usaha.

Telah banyak dilakukan penelitian tentang penggunaan daun binahong antara lain : 1) Potensi perasan daun binahong (Andredera cordifolia) sebagai antibakterial pada kultur media bakteri Staphylococcus aureus dan Esherichia coli penyebab mastitis klinis penyebab 
mastitis Sapi Perah (Trisunuwati dan $\begin{array}{lll}\text { Setyowati. 2017). 2) Pengaruh } & \text { 2) }\end{array}$ penggunaan tepung daun binahong (Andredera Cordifolia) (ten) (stennis) sebagai feed additive terhadap kualitas karkas ayam pedaging ( Muiz. 2016). 3) Penambahan serbuk daun binahong (Andredera Cardivolia) pada pakan terhadap respon imun, kelulushidupan dan status kesehatan udang windu (Penaeus monodon) yang diinfeksi vibrio harveyi (Utomo dkk, 2015). 4) Penambahan tepung daun binahong (Andredera Cordifolia) (Ten) Steenis dalam pakan untuk pencegahan infeksi Aeromonas hydrophila pada ikan lele (Wijaya, 2015). 5) Uji efektivitas salep ekstrak daun binahong (Andredera cordifolia (Ten) Steenis) pada kelinci (Oryctolagus cuniculus) yang terinfeksi bakteri Staphylococcus aureus (Paju dkk, 2013).

Dari beberapa penelitian sebelumnya mengenai daun binahong telah diolah menjadi serbuk, tepung, perasan, maupun salep untuk melihat dampak dari penambahan olahan daun binahong pada pakan ternak merupakan fakta bahwa daun binahong memiliki potensi yang menarik untuk diteliti lebih lanjut. Oleh karena itu, dalam penelitian ini memberikan perbedaan perlakuan terhadap daun binahong sebelum diberikan kepada ternak dalam hal ini ayam petelur yaitu dengan dilakukan fermentasi.

\section{B. METODE PENELITIAN}

Penelitian ini dilaksanakan di Desa Taulo, Kecamatan Alla, Kabupaten Enrekang Provinsi Sulawesi Selatan.

Metode yang digunakan untuk analisis potensi kebergunaan pakan fermentasi tepung daun binahong yaitu trial end error untuk pencampuran komponen bahan pakan.

Trial and error merupakan metode paling sederhana, yaitu dengan menghitung beberapa kombinasi pencampuran bahan pakan secara manual, dengan coba-coba untuk mendapatkan kombinasi pencampuran bahan pakan yang paling mendekati, cocok atau sesuai dengan komposisi nutrisi pakan jadi yang diinginkan.

Metode trial end error yang dirumuskan sebagai berikut :

Nutrisi Formulasi Ransum

$$
=\frac{(N 1 \times K 1)+(N 2 \times K 2)+(N 3 \times K 3)+\cdots}{K 1+K 2+K 3+\cdots}
$$

Keterangan :

$\mathrm{N}$ : Nutrisi bahan pakan

$\mathrm{K}$ : Komposisi bahan pakan dalam ransum

Dengan 4 formulasi pakan yaitu :

1. $\mathrm{P} 0=$ Pakan basal tanpa penambahan tepung daun binahong

2. $\mathrm{P} 1=\mathrm{P} 0+5 \%$ Tepung Daun Binahong

3. $\mathrm{P} 2=\mathrm{P} 0+10 \%$ Tepung Daun Binahong

4. $\mathrm{P} 3=\mathrm{P} 0+15 \%$ Tepung Daun Binahong 
Tabel 1. Komposisi Ransum

\begin{tabular}{lcccc}
\hline \multirow{2}{*}{ Bahan Pakan } & \multicolumn{4}{c}{ Komposisi } \\
\cline { 2 - 5 } & P0 & P1 & P2 & P3 \\
\hline Jagung & $40 \%$ & $38 \%$ & $36 \%$ & $34 \%$ \\
Dedak & $30 \%$ & $28,5 \%$ & $27 \%$ & $25,5 \%$ \\
Konsentrat & $30 \%$ & $28,5 \%$ & $27 \%$ & $25,5 \%$ \\
Tepung Daun & $0 \%$ & $5 \%$ & $10 \%$ & $15 \%$ \\
Binahong & & & & \\
\hline Total & $100 \%$ & $100 \%$ & $100 \%$ & $100 \%$ \\
\hline
\end{tabular}

Kemudian menggunakan EM4

untuk fermentasi pakan dengan konsentrasi 3\% dilarutkan dalam air sebanyak 20\% dari berat ransum, kemudian difermentasi selama 24 jam. Ransum tersebut akan diberikan kepada ayam petelur dengan tujuan untuk meningkatkan sistem imun pada ternak.

\section{HASIL DAN PEMBAHASAN}

\section{Analisis Potensi Pakan}

Nilai nutrisi ransum dari setiap formulasi mulai dari P0, P1, P2 dan P3 dapat dihitung kadar nutrisi dengan menggunakan metode trial end error dengan tujuan melihat potensi nutrisi ransum dalam memenuhi kebutuhan nutrisi ayam petelur seperti pada Table. 2 .

Tabel 2. Kebutuhan Nutrisi Ayam Petelur Fase Layer

\begin{tabular}{lcc}
\hline Parameter & Persyaratan $(\%)$ & Keterangan \\
\hline Kadar air & 14 & Maksimal \\
Protein kasar & 16 & Minimal \\
Lemak kasar & 7 & Maksimal \\
Serat kasar & 7 & Maksimal \\
Abu & 14 & Maksimal \\
Kalsium & 4,25 & Maksimal \\
Phosfor & 1,00 & Maksimal \\
\hline Sumber : Badan Standarisasi Nasional. 2006.
\end{tabular}

Bahan pakan dalam ransum terdiri dari jagung, dedak, konsentrat dan tepung daun binahong. Berikut tabel kandungan nutrisi dari masing-masing bahan pakan:

Tabel 3. Kandungan Nutrisi Jagung

\begin{tabular}{lc}
\hline Parameter & Kadar $(\%)$ \\
\hline Kadar air & 13,2 \\
Abu & 2.15 \\
Protein Kasar & 10.8 \\
Lemak Kasar & 4.28 \\
Serat Kasar & 3.53 \\
Kalsium & 0.23 \\
Phospor & 0.41 \\
\hline Sumber : Dairy Feed IPB, 2017.
\end{tabular}

Tabel 4. Kandungan Nutrisi Dedak

\begin{tabular}{lc}
\hline Parameter & Kadar (\%) \\
\hline Kadar Air & 12,3 \\
Abu & 13.6 \\
Protein Kasar & 12 \\
Lemak Kasar & 8.64 \\
Serat Kasar & 13.9 \\
Kalsium & 0.09 \\
Phospor & 1.39 \\
\hline Sumber : Dairy Feed IPB, 2017. &
\end{tabular}

Tabel 5. Kandungan Nutrisi Konsentrat

\begin{tabular}{lc}
\hline Parameter & Kadar $(\%)$ \\
\hline Kadar Air & 12 \\
Abu & 15 \\
Protein Kasar & 29 \\
Lemak Kasar & 2 \\
Serat Kasar & 10 \\
Kalsium & 3 \\
Phospor & 1.2 \\
\hline
\end{tabular}
Sumber : Yusri, 2015.

Tabel 6. Kandungan Tepung Daun Binahong

\begin{tabular}{lc}
\hline Parameter & Kadar (\%) \\
\hline Kadar Air & 5,46 \\
Abu & 28,7 \\
Protein Kasar & 14,8 \\
Lemak Kasar & 5,2 \\
Serat Kasar & 8,08 \\
Kalsium & 1,28 \\
Phospor & 0,46 \\
\hline Sumber : Widodo dkk, 2016.
\end{tabular}

Berdasarkan kandungan nutrisi dari setiap bahan pakan, maka dapat dihitung jumlah kandungan nutrisi dari setiap formulasi pakan dengan mengunakan 
metode trial end error. Berikut tabel hasil perhitungan kandungan nutrisi dari setiap formulasi ransum,

Tabel 7. Kandungan Nutrisi Formulasi Ransum

\begin{tabular}{lcccc}
\hline \multirow{2}{*}{ Parameter } & \multicolumn{4}{c}{ Kadar $(\%)$} \\
& PO & P1 & P2 & P3 \\
\hline Kadar Air & 8,88 & 8,71 & 8,54 & 8,37 \\
Abu & 8,78 & 9,77 & 10,77 & 11,77 \\
Protein Kasar & 16,62 & 16,53 & 16,44 & 16,35 \\
Lemak Kasar & 4,59 & 4,62 & 4,65 & 4,68 \\
Serat Kasar & 9,21 & 9,15 & 9,10 & 9,04 \\
Kalsium & 1,02 & 1,03 & 1,05 & 1,06 \\
Phospor & 0,94 & 0,92 & 0,89 & 0,87 \\
\hline \multicolumn{4}{l}{ Keterangan: Hasil Perhitungan dengan metode trial end error. }
\end{tabular}

Berdasarkan hasil perhitungan pada tabel 7 dapat dilihat perbandingan dari setiap formulasi ransum bahwa parameter kadar air, protein kasar, abu, lemak kasar, dan phosphor dari setiap formulasi pakan mampu memenuhi syarat kebutuhan nutrisi pada tabel 2. Namun, parameter serat kasar dan kalsium dalam formulasi pakan tidak memenuhi syarat kebutuhan nutrisi pada tabel 2. Berikut histogram perbandingan kadar nutrisi ransum $\mathrm{P} 0$, P1, P2, dan P3 pada Tabel 7 dengan kebutuhan nutrisi pada Tabel 2.

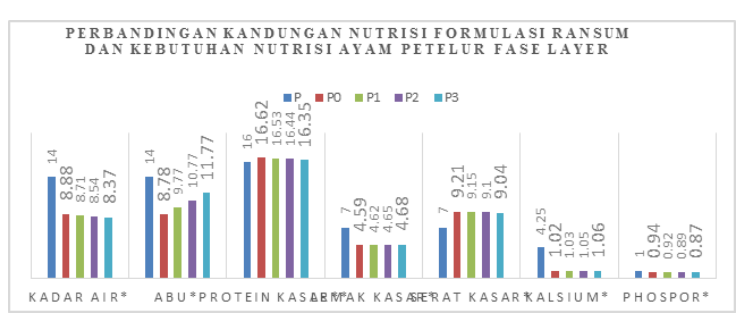

Gambar 1. Histogram Perbandingan Hasil

Perhitungan Nutrisi P0, P1, P2 dan P3 dengan Kebutuhan Nutrisi Ayam Petelur Fase Layer

Ket. P (Kebutuhan Nutrisi Ayam Petelur Fase Layer), * (Nilai Maksimal P), ** (Nilai Minimal P)
Kandungan serat kasar dan kalsium belum memenuhi syarat kebutuhan nutrisi ayam petelur fase layer maka dari itu, dilakukan fermentasi menggunakan EM4. Dalam penelitian (Santoso, 2007) menyebutkan bahwa EM4 menghasilkan sejumlah besar enzim mencerna serat kasar seperti selulase dan mannase. Keuntungan Lactobacillus dalam EM4 dalam mencerna serat kasar adalah karena bakteri tidak menghasilkan serat kasar dalam aktivitasnya, sehingga mereka lebih efektif dalam menurunkan serat kasar dari pada ragi dan jamur.

Sedangkan kekurangan kalsium dalam ransum dapat dipenuhi dengan meningkatkan kecernaan nutrisi pakan. Meningkatnya kecernaan nutrisi pakan tentu akan memaksimalkan absobrsi nutrisi oleh ternak. Menurut (Amin dkk, 2015) fermentasi berpengaruh terhadap peningkatan kadar komposisi kimia dan kecernaan jerami padi.

Penambahan fermentasi tepung daun binahong dalam pakan tentu memiliki potensi yang baik untuk menjaga kesehatan dan meningkat kekebalan tubuh (system imun) pada ternak. pakan fermentasi basah akan memperbaiki mikrobia saluran pencernaan sehingga akan memperbaiki imunitas (Hasan dkk, 2016). Imunitas 
yang baik berdampak baik bagi kesehatan itik yang mengkonsumsi pakan fermentasi (Allaily dkk, 2017). Penambahan tepung daun binahong sampai level 6\% dapat mempertahankan performa produksi telur puyuh (Mahadika, 2019).

Hasil uji kualitatif kandungan fitokimia tepung daun binahong (kandunagan total fenol, total flafonoid, saponin, dan total alkaloid) disajikan dalam Tabel 8.

Tabel 8. Kandungan Fitokimia Tepung Daun Binahong

\begin{tabular}{ll}
\hline Fitokimia & Kadar $(\mathrm{mg} / \mathrm{kg})$ \\
\hline Total fenol & 85,30 \\
Total Flafonoid & 47,40 \\
Saponin & 66,00 \\
Total Alkoloid & 2,60 \\
\hline Sumber : Widodo, dkk 2016 &
\end{tabular}

Total fenol terdiri dari fenol sederhana, asam fenolat, kumarin, tannin, dan flavonoid. Flavanoid merupakan golongan terbesar dari senyawa fenol, senyawa fenol mempunyai sifat efektif menghambat pertumbuhan virus, bakteri dan jamur. Senyawa flavanoid dan turunannya memilki dua fungsi fisiologi tertentu, yaitu sebagai bahan kimia untuk mengatasi serangan penyakit (sebagai antibakteri) dan antivirus bagi tanaman. Mekanisme kerja flavonoid dalam menghambat pertumbuhan bakteri, antara lain bahwa flavonoid menyebabkan terjadinya kerusakan permeabilitas dinding sel bakteri. Saponin merupakan metabolit sekunder tanaman memiliki sifat yang mampu berikatan dengan kolesterol dan ergosterol pada membrane sel, sebagai akibatnya jika membrane sel kontak dengan saponin makan membrane sel akan segera mengalami lisis (Herrmann and Wink, 2011 dalam Widodo, dkk 2016).

Alkaloid merupakan golongan zat tumbuhan sekunder yang terbesar. Alkaloid memiliki kemampuan sebagai antibakteri. Mekanisme yang diduga adalah dengan cara mengganggu komponen penyusun peptidoglikan pada sel bakteri, sehingga lapisan dinding sel tidak terbentuk secara utuh dan menyebabkan kematian sel tersebut (Robinson, 1995 dalam Widodo, dkk 2016).

\section{Fermentasi}

Fermentasi merupakan proses pemecahan senyawa organik menjadi senyawa yang lebih sederhana dengan melibatkan mikroorganisme. Secara umum, fermentasi menghasilkan produk yang lebih sederhana dan lebih mudah dicerna dari bahan asalnya. Melalui teknologi fermentasi, dapat dihasilkan perbaikan dan peningkatan nilai nutrisi bahan baku pakan sehingga dapat dimanfaatkan secara optimal untuk bahan baku pakan. Fermentasi adalah suatu 
proses perubahan kimiawi dari senyawasenyawa organik (karbohidrat, lemak, protein, dan bahan organik lain) baik dalam keadaan aerob maupun anaerob, melalui kerja enzim yang dihasilkan oleh mikroba. Produk terfermentasi umumnya mudah diurai secara biologis dan mempunyai nilai nutrisi yang lebih tinggi dari bahan asalnya, hal tersebut selain disebabkan oleh sifat mikroba yang katabolik atau memecah komponenkomponen yang komplek menjadi lebih sederhana sehingga lebih mudah dicerna, tetapi juga dapat mensintesis beberapa vitamin yang komplek. Manfaat fermentasi antara lain dapat mengubah bahan organik kompleks seperti protein, karbohidrat, dan lemak menjadi molekulmolekul yang lebih sederhana dan mudah dicerna, mengubah rasa dan aroma yang tidak disukai menjadi disukai dan mensintesis protein (Pamungkas, 2011).

Upaya untuk memperbaiki kualitas gizi, mengurangi, atau menghilangkan pengaruh negatif dari bahan pakan tertentu dapat dilakukan dengan penggunaan mikroorganisme melalui proses fermentasi. Fermentasi juga dapat meningkatkan nilai kecernaan, menambah rasa dan aroma, serta meningkatkan kandungan vitamin dan mineral. Pada proses fermentasi dihasilkan pula enzim hidrolitik serta membuat mineral lebih mudah untuk diabsorbsi oleh ternak (Winarno, 2000). Beberapa peneliti melaporkan adanya perubahan komposisi zat-zat makanan dalam substrat melalui fermentasi dengan menggunakan Effective Microorganism 4 (EM4).

Mikroorganisme alami yang terdapat dalam EM4 bersifat fermentasi (peragian) dan sintetik, terdiri dari lima kelompok mikroorganisme dari golongan ragi, Lactobacillus, jamur fermentasi, bakteri fotosintetik, dan Actinomycetes (Paramita, 2002 dalam Tifani dkk., 2014). Effective Microorganism 4 (EM4) adalah campuran dari berbagai mikroorganisme yang dapat dimanfaatkan sebagai sumber inokulum dalam meningkatkan kualitas pakan. Penambahan EM4 sebanyak $10 \%(\mathrm{v} / \mathrm{b})$ pada substrat mampu menurunkan kadar serat bahan (Sandi dan Saputra, 2012). Penggunaan pakan yang difermentasi dengan EM4 menyebabkan peningkatan daya cerna dan kandungan protein bahan (Winedar, 2006).

\section{KESIMPULAN DAN SARAN}

Hasil penelitian dan pembahasan dapat ditarik kesimpulan bahwa analisis potensi kandungan nutrisi dengan menggunakan metode trial end error pada setiap formulasi ransum dapat disimpulkan bahwa semua formulasi 
ransum mampu memenuhi parameter kebuhuhan nutrisi pada ayam petelur fase layer antara lain kadar air, protein kasar, abu, lemak kasar, dan phosphor.

Dengan melihat potensi yang terkandung dalam setiap formulasi ransum melalui perhitung dengan metode trial end error tentu menarik untuk dilakukan penelitian, penerapan, dan pendalaman lebih lanjut untuk memastikan tingkat kebergunaan pakan fermentasi tepung daun binahong (Andredera cordifolia) terhadap peningkatkan sistem imun ayam petelur sehingga mampu digunakan oleh peternak untuk mengurangi resiko kerugian dalam masa produksi.

\section{DAFTAR PUSTAKA}

Abbas, K.A., Lichtman, A.H. dan Pillai, S., 2007. Celluler and Moleculer Immu-nology 6th Ed, Saunders, USA.

Allaily T, Nahrowi R, Ridla M, Yaman MA, Setiyono A. 2017. Effects of organic acids on Salmonella enteritidis growth inhibition and ileum surface area in laying ducks fed anaerobically fermented feed. Int J Poult Sci. 16:98-104.

Amin, M., Hasan, S.D., Yanuarianto, O., Iqbal, M. 2015. Pengaruh Lama Fermentasi Terhadap Kualitas Jerami Padi Amoniasi yang Ditambah Probiotik Bacillus Sp. (Effect of Fermentation Duration on Quality of Ammoniation of Rice Straw with Probiotic Bacillus sp.). Fakultas Peternakan Universitas Mataram. Jurnal Ilmu dan Teknologi
Peternakan Indonesia Volume 1 (1) : 11 - 17; Desember 2015 ISSN : 2460-6669

Anonim, 2011. Telur dan Problematikanya. Info Medion, Edisi November, 2011.

Badan Standarisasi Nasional. 2006. Pakan Ayam Ras Petelur (layer). SNI 013929-2006.

Dairy Feed IPB, 2017. Informasi detail pakan. Dairy feed online. http://dairyfeed.ipb.ac.id. Diakses pada 1 september 2020

Dirjen Peternakan dan Kesehatan Hewan. 2014. Populasi ayam ras petelur .Kementrian pertanian RI, Jakarta.

Hasan S.A.J, Lokman I.H, Saad A.N, Zuki A.B.Z, Kassim A.B. 2016. Research article effects of dietary supplementation of wet fermented feed with probiotic on the production performance of Akar Putra chicken. Asian J Poult Sci. 10:72-77.

Mahadika, R.B., Kismiati, S. dan Muryani, R. 2019. Pengaruh Penambahan Tepung Daun Binahong (Andredera Cordifolia) Terhadap Performa Produksi Puyuh (Coturnix coturnix japonica). Fakultas Peternakan dan Pertanian, Universitas Diponegoro. Artikel Pemakalah Paralel p-ISSN: 2527533X. Seminar Nasional Pendidikan Biologi dan Saintek (SNPBS) ke-IV 2019.

Muiz, A. 2016. Pengaruh Penggunaan Tepung Daun Binahong (Andredera Cordifolia) (Ten) (Stennis) Sebagai Feed Additive Terhadap Kualitas Karkas Ayam Pedaging. J. Agrisains 17 (1) : $54-61$.

Pamungkas, W. 2011. Teknologi Fermentasi, Alternatif Solusi Dalam Upaya Pemanfaatan Bahan Pakan Lokal. Loka Riset Pemuliaan dan Teknologi Budidaya Perikanan Air 
TawarMedia Akuakultur Volume 6 Nomor 1.

Sandi, S., dan Saputra, A. 2012. The Effect of Effective Microorganisms4 (Em 4) Addition on the Physical Quality of Sugar Cane Shoots Silage. In International Seminar on Animal Industry.

Santoso, U. 2007. Change In Chemical Composition Of Cassava Leaves Fermented By Em4. JSPI, 2(2), 912.

Tifani, M. A., Kumalaningsih, S., dan Mulyadi, A. F. 2014. Produksi Bahan Pakan Ternak Dari Ampas Tahu Dengan Fermentasi Menggunakan Em4 (Kajian Ph Awal Dan Lama Waktu Fermentasi. Fakultas Teknologi Pertanian, Universitas Brawijaya. Skripsi.

Trisunuwati, P. dan Setyowati, E. 2017. Potensi Perasan Daun Binahong (Andredera Cordifolia) Sebagai Antibakterial pada Kultur Media Bakteri Staphylococcus Aureus dan Esherichia Coli Penyebab Mastitis Klinis Penyebab Mastitis Sapi Perah. Jurnal Ilmu-Ilmu Peternakan 27 (1): $18-27$.

Widodo, N., Wihandoyo, Dono, N.D dan Zuprizal 2016. Potensi Tepung Daun Binahong (Andredera Cordifolia (Ten.) Steenis) Sebagai Fitobiotik Pada Pakan Ayam Broiler. Prosiding Seminar Nasional Optimalisasi Teknologi dan Agribisnis Peternakan dalam Rangka Pemenuhan Protein Hewan Asal Ternak ISBN 978-602-100442-5.

Wijaya, I. 2015. Penambahan Tepung Daun Binahong Andredera Cordifolia (Ten) Steenis Dalam Pakan Untuk Pencegahan Infeksi Aeromonas Hydrophila Pada Ikan Lele. Skripsi. Departemen Budidaya Perairan, Fakultas Perikanan dan
Ilmu Kelautan, Institut Pertanian Bogor.

Winarno, F. G. 2000. Kimia Pangan dan Gizi. PT Gramedia Pustaka Utama. Jakarta.

Winedar, H. 2006. Daya Cerna Protein Pakan, Kandungan Protein Daging, dan Pertambahan Berat Badan Ayam Broiler setelah Pemberian Pakan yang Difermentasi dengan Effective Microorganisms-4 (EM4). Bioteknologi 3 (1): 14-19.

Yusri, 2015. Performa Ayam Ras Petelur Pada Periode Awal Bertelur Dengan Kombinasi Berat Awal Bertelur Dengan Kombinasi Berat Badan Pre-Layer Dan Pemberian Jumlah Pakan Yang Berbeda. Fakultas Peternakan, Universitas Hasanuddin, Makassar. Skripsi. 